\title{
Efficacy of Some Medicinal and Aromatic Plants Combined with Different Biocides Against Fusarium oxysporum f.sp. lycopersici-Meloidogyne incognita Disease Complex in Tomato
}

\section{Farag M.F. . ; Ghebrial, E.W.R ${ }^{2}$ and Zawam, H.S ${ }^{3}$}

1- Vegetable Dis. Res. Dept., Plant Pathology Research Institute, ARC, Giza, Egypt.

2- Medicinal and Aromatic Plant Dis. Res. Dept., Plant Pathology Research Institute, ARC, Giza, Egypt.

3- Nematode Res. Dept., Plant Pathology Research Institute, ARC, Giza, Egypt.

Tn a field experiment the efficacy of some medicinal and aromatic plant species namely, Damsisa, Marigold, Marjoram and Peppermint as intercropping and Castor bean, Lantana and Wild mint as soil amendments either alone or combined with two biocides (Blight stop and Clean root) against Fusarium oxysporum f.sp. lycopersici-Meloidogyne incognita disease complex in tomato plants (Hybrid 85) was studied. All treatments had a positive effect on the reduction of disease severity, population of the fungus in the soil and nematode parameters (no. of galls, egg masses, developmental stages, nematode population in soil and its reproduction rate) with significant increase in plant height and fruits yield at the end of experiment. Combined treatments between biocides and each of the tested plant species effectively enhanced the level of disease reduction compared to each single treatment. Blight stop treatment plus any plant species tested was the most effective in decreasing disease complex than combined treatments with Clean root. Treatment of tomato- marjoram intercropping combined with the biocide Blight stop followed by combined treatment between marjoram and the biocide Clean root and wild mint-amended soil combined with Blight stop treatment were the most effective in this concern. Although, intercropping of damsisa and peppermint with tomato plants reduced severity of disease complex but affected plant growth and fruits yield to the lowest value.

Keywords: Medicinal and aromatic plant, Fusarium oxysporum f.sp. lycopersici, Meloidogyne incognita and tomato.

Tomato (Solanum lycopersicum L.) is one of the most important vegetable crops grown in Egypt as well as in the world. Fusarium wilt caused by Fusarim oxysporum f.sp. lycopersici (Sacc. W.C. Snyder et al., 2003) and Root knot disease, caused by Meloidogyne spp., is the most economically important disease currently impacting the cultivation of tomato in Egypt and worldwide. The nematode not only causes direct damage to plants at their own, but also helps fungi, bacteria and plant viruses generally 
to invade host plant leading to the development of a disease complex. The combination of nematode and fungus often results in synergistic interaction, wherein the crop loss is greater than expected from either pathogen alone or an additive effect of the two pathogens together (Kumar et al., 2017). Also, interactions of $F$. oxysporum and Meloidogyne spp. can lead to a breakdown of resistance to an unidentified race of the Fusarium wilt pathogen (Uma Maheshwari et al., 1997). The most common method to control the nematode-fungal disease complex is by using fungicides and nematicides, but frequent and indiscriminate use of these chemicals leads to environmental pollution and development of fungicide resistance in pathogens. Thus, the use of antagonistic/nematicidal plants grown in rotation, conjunction with vegetables or field crops or used as a soil amendment alone and in combination with bioagents i.e., Trichoderma sp. and Bacillus sp. have been reported to reduce the root-knot wilt disease complex on many crops (Munawar et al., 2015 and Abd-El-Khair et al., 2018) and become a promising alternative to chemical control in the management of disease complex. Fifty seven plant families have fungicidal and nematicidal effects (Sukul, 1992), including Asteraceae, Verbenaceae, Lamiaceae and Euphorbiaceae, thus the need to consider damsisa, marigold, lantana, marjoram, mint, wild mint and castor bean, are relatively common sources of antifungal and nematicides in these respective families (Mafeo and Mashela, 2010 and Nahak \& Sahu, 2017). Studies on the mechanisms of disease control by plant products have revealed that their biologically active constituents may have either direct antimicrobial activity (Zaker, 2014) or induce host plants defense response resulting in reduction of disease development (Schneider and Ullrich, 1994). The toxic metabolites naturally produced by microorganisms may be responsible for keeping low level of nematode and fungi populations. Among the fungal and bacterial antagonists, various species of Trichoderma and Bacillus have shown promising results in the control of wilt fungus-root knot disease complex and enhance the plant growth (Munawar et al., 2015). Therefore, the present study aim was to determine and compare the effect of some medicinal and aromatic plants as intercropping, soil amendments and/or biocides in individual and in combination against Fusarium oxysporum f.sp. lycopersici-Meloidogyne incognita disease complex in tomato and their role on plant growth under field conditions.

\section{Materials and Methods}

A two-year field experiment was conducted in the Experimental Farm of Sids Horticultural Research Station, Agric. Res. Center, Beni-Sweif governorate during the seasons of 2016 and 2017 to evaluate the efficacy of some medicinal and aromatic plants alone or combined with some biocides against Fusarium oxysporum f.sp. lycopersici-Meloidogyne incognita disease complex in tomato. The soil of the experimental field was clay in texture ( $16.5 \%$ sand, $30.1 \%$ silt, $53.4 \%$ clay), pH of 8.1, EC $1.2 \mathrm{dSm}^{-1} ; 1.3 \%$ organic matter and 26.2, 10.1 and $176 \mathrm{ppm}$ available $\mathrm{N}, \mathrm{P}$ and $\mathrm{K}$, respectively. The field has long history of tomato wilt and root-knot nematodes where this field was cultivated with a tomato crop before. A sample of soil was taken

Egypt. J. Phytopathol., Vol. 46, No. 2 (2018) 
randomly to determine the distribution of the wilt fungus and the root-knot nematodes populations in the field as follow: Samples of soil and roots were collected from infected field from the rhizosphere of tomato crop to the root depth, in the similar manner totally about 10-15 spots were selected randomly for taking soil and root samples representing the whole field. The nematode population from soil and root samples was estimated. Fungal propagules were isolated from soil samples, while root samples were used for detection of the fungus associated with wilted plants. The field was cropped to susceptible hosts (beans) in the winter to maintain fungus-nematode population levels. Experimentation started in the summer of 2016 and 2017.

The tested plant species were damsisa (Ambrosia maritima L.), marigold (Tagetes erecta L.) belong to family Asteraceae, marjoram (Origanum majorana L.), peppermint (Mentha piperita L.), wild mint (Mentha longifolia L.) belong to family Lamiaceae, castor bean (Ricinus communis L.) belongs to family Euphorbiaceae, lantana (Lantana camara L.) belongs to family Verbenaceae. Damsisa, marigold, peppermint and marjoram were used as intercropping, while wild mint, castor bean and lantana were used as soil amendments.

For intercropping: Damsisa, marigold, peppermint and marjoram were planted immediately after the termination of tomato plants. Tomato seedlings were planted in one side of row and the tested plants were planted in the opposite side.

For soil amendments: Leaves and flowers of wild mint, lantana and seeds of castor bean were separately air-dried under shade and grounded. The specified dried and ground leaves, flowers and seeds were then mixed thoroughly in a layer 10 to $30 \mathrm{~cm}$ below the soil surface at the rate of $5 \mathrm{~g} \mathrm{~kg}^{-1}$ of soil, equivalent to 10 ton ha ${ }^{-1} .90 \mathrm{~kg} / \mathrm{fed}$. of nitrogen in the form of urea were added to amended soil and watered to facilitate decomposition of organic matter (Hussain et al., 2011). Two weeks after amendment, tomato seedlings were planted in amended plots.

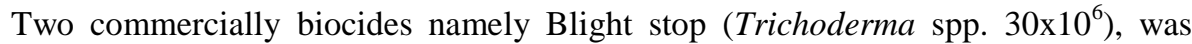
used at the rate of 1 liter/100 liter of water/fed. and Clean root $\left(\right.$ B. subtilis $\left.30 \times 10^{6} \mathrm{cfu} / \mathrm{g}\right)$, was used at the rate $500 \mathrm{~g} / 100$ liter of water/fed., were kindly obtained from (Central Lab. of Organic Agriculture, ARC. Giza) and were used alone or combined with plant species tested. Before the transplanting, roots of tomato seedlings were dipped into each biocide for $2 \mathrm{~h}$. and then transplanted to the field soil. However, Clean root was used as a field application monthly after cultivation time until the end of the growing season. Blight stop was used as a field application two weeks after cultivation time and repeated monthly through the growing season. Untreated plots and/or treated with a fungicide, Moncut (500 g/fed.) and a nematicide, Oxamyl (3L /fed.) were used two times to the soil. The first one at transplanting of tomato and the second after one month from the first application. Uniform seedlings of tomato Hybrid 85 (at the fifth truly leaf) were transplanted in the experimental field plots. 
Field plots $(3 \times 3.5 \mathrm{~m})$ were used in complete randomized block design. Three plots were used as replicates for each treatment as well as for untreated control treatment. Chemical fertilizers were added at the recommended dose of nitrogen, phosphorus and potassium fertilizers for all treatments. Weeds were removed by manual operations as needed and plants were irrigated regularly as necessary, throughout the growing season in order to maintain constant growth. Disease incidence and severity were estimated as follow:

\section{Disease incidence:}

Percentage of disease incidence was recorded as the number of diseased plants relative to the number of growing plants for each treatment, and then the average disease incidence was calculated. Efficiency was calculated using the formula:

$$
\text { Efficiency } \%=[\mathrm{C}-\mathrm{T}] / \mathrm{C} \times 100
$$

Whereas: $\mathrm{C}$ and $\mathrm{T}$ are the percentage of disease incidence in control and treated plants, respectively.

\section{Disease severity:}

Disease severity was estimated at the end of experiments, as a wilting percent using the rating scale according to (Abo-Elyousr and Mohamed, 2009).

$$
\text { Disease severity } \%=\frac{[\Sigma(\mathrm{n} \mathrm{x} \mathrm{c})]}{(\mathrm{N} \times \mathrm{C})} \times 100
$$

Whereas: $\mathrm{n}=$ Number of infected plants, $\mathrm{c}=$ Category number, $\mathrm{N}=$ Total number of examined plants and $\mathrm{C}=$ The highest category number of infection.

Fruits in each plot were harvested and weighed. At the final harvest, the tomato root systems were dug up and taken to the laboratory to evaluate root galling and for nematode analysis. The roots were then washed to get rid of the adhering and particles to determine the number of root knot galls, juveniles in soil, eggs $15 \mathrm{gm}$ roots, developmental stages in the roots. The number of nematode larvae (in $250 \mathrm{~cm}^{3}$ soil) and RF (Reproduction Factor) was determined according to Norton (1978).

$$
\begin{array}{cc}
\text { Reproduction Factor }(\mathrm{RF})= & \text { No. eggs }+ \text { Developmental stages }+ \text { Free nematode in soil } \\
\begin{array}{c}
\text { Developmental stages }(\mathrm{DS})= \\
\text { number of developed juveniles (third and fourth stages) } \\
\text { embedded in the roots }
\end{array} \\
\text { Final population }= & \text { No. eggs }+ \text { Developmental stages }+ \text { Free nematode in soil }
\end{array}
$$

To assess the influence of medicinal and aromatic plants tested on population of wilt fungus as well as the bioagents (Bacillus and Trichoderma sp.). Soil samples were collected firstly after 7 days from transplanting (DAT), and at two month intervals, i.e. 
at 60 and 120 days, from each treatment as well unamended control. Samples from three random spots around the plants in each replicate per treatment were collected using a trowel to a depth of $20 \mathrm{~cm}$, then transported to the laboratory, air-dried, and processed within $24 \mathrm{~h} .1 \mathrm{~g}$ of each soil sample suspended in $9 \mathrm{ml}$ sterile water, stirred for $10 \mathrm{~min}$ and serially diluted. Final dilutions of $10^{3}$ to $10^{4}$ were placed on Czapek's medium for asses $F$. oxysporum population and Trichoderma-selective medium (TSM) for Trichoderma (Elad et al., 1981), amended with $300 \mathrm{mg} / 1$ streptomycin and $50 \mu \mathrm{g} \mathrm{ml}^{-1}$ rose Bengal. Plates were incubated at $25^{\circ} \mathrm{C}$ for 7 days before recording the number of colony propagules of fungi. For isolation of bacteria, final dilutions of $10^{5}$ to $10^{6}$ were placed on nutrient agar medium and incubated at $25^{\circ} \mathrm{C}$ for $48 \mathrm{~h}$ before recording the number of bacterial colony.

Data were statistically analyzed for computing L.S.D. test at $5 \%$ probability according to the procedure outlined by Snedecor and Cochran (1989).

\section{Results}

Data in Table, 1 show that all tested plant species significantly reduced population of Fusarium oxysporum in the soil and hence incidence and severity of wilt disease in the two growing seasons compared to control treatment. In this respect, intercropping of marjoram with tomato plants showed the highest efficacy compared to the other plant species treatments where it reduced incidence, severity of Fusarium wilt disease by $58.1,49.1 \%$, respectively and population by $65.8 \%$ followed by wild mint and castor bean as soil amendment which lies in the same statistical group with the values of marjoram treatment except in fungus population parameter. The corresponding reductions in disease incidence were 57.7, 54.4\% and in disease severity, being 48.1 and $45.3 \%$ in the first growing season (2016). On the other hand, the reduction values in fungus population due to these treatments were 64.5 and $53.9 \%$, respectively which statistically lies in the same group. Intercropping of peppermint showed moderate effect with values statistically not differ with the value of castor bean-amended soil treatment followed by marigold plant as intercropping treatment and lantana-amended soil treatment without significant differences between them. Meanwhile, intercropping of damsisa with tomato plants showed the lowest effect on Fusarium wilt and its population in soil. The same trend was observed in the second growing season.

The root knot nematode (M. incognita) parameters, (number of galls, egg mass and developmental stages per root system and number of nematode in soil as a final population were significantly reduced with the treatments compared with untreated control (Table, 2). In the season of 2016, maximum inhibition was observed in plot intercropped with marjoram followed by wild mint and castor bean-amended soil treatment. The highest and lowest reduction of these variables was observed in plots where marjoram and damsisa intercropped with tomato because they reduced number of galls to $26 \& 380$, number of egg mass to $23 \& 178$ and developmental stage to $51 \&$ 
331 per root system, respectively. While, lantana as soil amendment and peppermint, marigold as intercropping treatments showed moderate effect.

Table (1): Efficiency of different medicinal and aromatic plants against Fusarium wilt of tomato plants and their effects on disease severity and population of $F$. oxysporum f.sp. lycopersici $\left(10^{4}\right.$ spore/g dry soil $)$ during the two growing seasons.

\begin{tabular}{|c|c|c|c|c|c|c|c|c|c|c|}
\hline \multirow[b]{2}{*}{ 芑 } & \multicolumn{4}{|c|}{ Season of 2016} & \multicolumn{4}{|c|}{ Season of 2017} & \multicolumn{2}{|c|}{$\begin{array}{c}\text { Mean of the } \\
\text { two growing } \\
\text { seasons } \\
\end{array}$} \\
\hline & 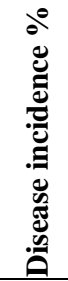 & 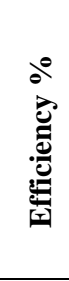 & 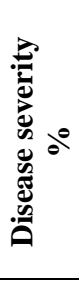 & 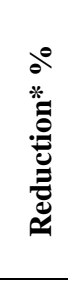 & 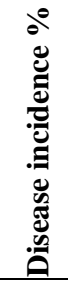 & 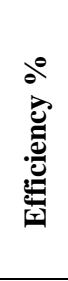 & 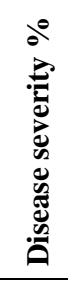 & 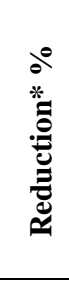 & 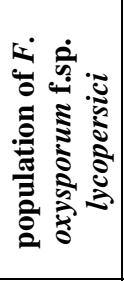 & 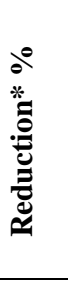 \\
\hline Castor bean & 43.7 & 54.4 & 42.3 & 45.3 & 42.0 & 57.0 & 40.6 & 49.6 & 3.5 & 53.9 \\
\hline Damsisa & 63.9 & 33.3 & 58.0 & 25.1 & 64.7 & 33.8 & 61.5 & 23.6 & 4.9 & 35.5 \\
\hline Lantana & 59.5 & 37.9 & 49.6 & 35.9 & 56.4 & 42.3 & 48.3 & 40.0 & 4.3 & 43.4 \\
\hline Marigold & 55.9 & 41.6 & 47.3 & 38.9 & 53.2 & 45.5 & 45.9 & 43.0 & 4.1 & 46.1 \\
\hline Marjoram & 40.1 & 58.1 & 39.4 & 49.1 & 36.3 & 62.8 & 34.5 & 57.1 & 2.6 & 65.8 \\
\hline Peppermint & 45.5 & 52.5 & 44.6 & 42.4 & 43.9 & 55.1 & 42.8 & 46.8 & 3.4 & 55.3 \\
\hline Wild mint & 40.5 & 57.7 & 40.2 & 48.1 & 38.8 & 60.3 & 38.3 & 52.4 & 2.7 & 64.5 \\
\hline $\begin{array}{l}\text { Moncut } \quad+ \\
\text { Oxamyl }\end{array}$ & 33.7 & 64.8 & 25.3 & 67.3 & 32.0 & 67.2 & 22.2 & 72.4 & 1.1 & 85.5 \\
\hline Control & 95.8 & 0.0 & 77.4 & --- & 97.7 & 0.0 & 80.5 & --- & 7.6 & --- \\
\hline L.S.D. at 0.05 & 3.9 & 4.2 & 3.1 & --- & 4.0 & 4.4 & 3.9 & --- & 0.3 & --- \\
\hline
\end{tabular}

* Reduction \% relative to the control.

The suppressive effect of the tested medicinal and aromatic plants was recorded as the nematode population in the soil at the end of the experiment was reduced. Significantly, the most effective treatments in reducing the final nematode population were the Moncut + Oxamyl and marjoram as intercropping over the other treatments. These treatments suppressed the nematodes in soil and final population to $50 \& 111$ and $64 \& 185$, respectively in the first growing season (2016) followed by wild mintamended soil treatment which reduced the no. of nematode larvae to 160 and final population to 260. Castor bean as soil amendment treatment gave the moderate effect followed by peppermint and marigold as intercropping treatments. The lowest nematode 
population reduction was observed in the soil samples obtained from plots planted with damsisa followed by lantana-amended soil treatment.

On the other hand, the reproduction rate of $M$. incognita was significantly suppressed by all the treatments as compared to untreated control plants. Reproduction factor of M. incognita was 1.69 in untreated control treatment but decreased to 0.09 by marjoram intercropping with tomato plants followed by wild mint as soil amendment (0.13) when compared with other treatments. The highest nematode reproduction factor was observed in plots planted with damsisa which recorded 0.88 followed by plots amended with lantana (0.63). The same trend was observed in the second growing season 2017.

Table (2): Effect of different medicinal and aromatic plants as intercropping or soil amendments on $M$. incognita development and reproduction during the two growing seasons 2016 and 2017 under field conditions.

\begin{tabular}{|c|c|c|c|c|c|c|}
\hline \multirow[t]{2}{*}{ Treatments } & 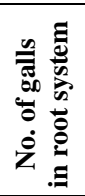 & 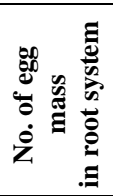 & 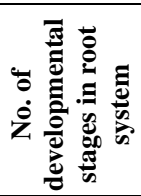 & 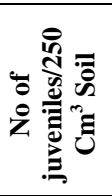 & 焉高 & 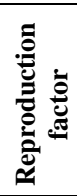 \\
\hline & \multicolumn{6}{|c|}{ Season of 2016 (Initial population, 2000) } \\
\hline Castor bean & 76 & $\mathbf{5 0}$ & 103 & 400 & 553 & 0.28 \\
\hline Damsisa & 380 & 178 & 331 & 1260 & 1769 & 0.88 \\
\hline Lantana & 204 & 124 & 312 & 820 & 1256 & 0.63 \\
\hline Marigold & 197 & 123 & 109 & 660 & 892 & 0.45 \\
\hline Marjoram & 26 & 23 & 51 & 111 & 185 & 0.09 \\
\hline Peppermint & 111 & 73 & 118 & 480 & 671 & 0.34 \\
\hline Wild mint & 31 & 22 & 78 & 160 & 260 & 0.13 \\
\hline Moncut + Oxamyl & 7 & 5 & 9 & $\mathbf{5 0}$ & 64 & 0.03 \\
\hline Control & 971 & 840 & 510 & 2020 & 3370 & 1.69 \\
\hline \multirow[t]{2}{*}{ L.S.D. at 0.05} & 5.8 & 6.7 & 7.7 & 20.7 & 72.9 & 0.01 \\
\hline & \multicolumn{6}{|c|}{ Season of 2017 (Initial population, 1500) } \\
\hline Castor bean & 77 & 50 & 87 & 330 & 467 & 0.31 \\
\hline Damsisa & 320 & 170 & 215 & 1060 & 1445 & 0.96 \\
\hline Lantana & 166 & 101 & 207 & 779 & 1087 & 0.72 \\
\hline Marigold & 140 & 84 & 98 & 601 & 783 & 0.52 \\
\hline Marjoram & 20 & 14 & 33 & 84 & 131 & 0.09 \\
\hline Peppermint & 99 & 75 & 103 & 370 & 548 & 0.37 \\
\hline Wild mint & 25 & 21 & 70 & 110 & 201 & 0.13 \\
\hline Moncut + Oxamyl & 8 & 4 & 9 & 20 & 33 & 0.02 \\
\hline Control & 995 & 890 & 611 & 4600 & 6101 & 4.07 \\
\hline L.S.D. at 0.05 & 5.0 & 6.2 & 7.0 & 27.5 & 86.5 & 0.03 \\
\hline
\end{tabular}

Egypt. J. Phytopathol., Vol. 46, No. 2 (2018) 
The treatments did not show any negative effects on the tomato plant growth except with tomato-peppermint and tomato-damsisa intercropping treatments. There were significant differences in the height of tomato plants $(\mathrm{cm})$ and the yield of fruits (ton/fed.) treated with the tested medicinal and aromatic plants over control plants (Table, 3). The highest increase was obtained with Moncut + Oxamyl treatment which scored $131.9 \& 151.9 \%$ and $231.6 \& 284.0 \%$ in the two growing seasons, respectively followed by plots of tomato-marjoram intercrop and wild mint-amended soil treatments with significant differences between them. The increase in plant height due to these treatments was $109.8 \& 90.9 \%$ and in fruits yield was $170.2 \& 122.8 \%$ in 2016 growing season and $132.8 \& 109.4 \%, 222.0$ \& $160.0 \%$ in 2017 growing season, respectively.

Table (3): Effect of different medicinal and aromatic plants as intercropping or soil amendments on plant height $(\mathrm{cm})$ and tomato fruits yield (ton/fed.) during the two growing seasons 2016 and 2017 under field conditions.

\begin{tabular}{|c|c|c|c|c|}
\hline \multirow{2}{*}{ Treatments } & \multicolumn{4}{|c|}{ Season of 2016} \\
\hline & Plant height & Increase* \% & Fruits yield & Increase $^{* \%}$ \\
\hline Castor bean & 74.9 & 75.4 & 11.0 & 93.0 \\
\hline Damsisa & 53.5 & 25.3 & 7.2 & 26.3 \\
\hline Lantana & 60.4 & 41.5 & 9.9 & 73.7 \\
\hline Marigold & 66.3 & 55.3 & 9.4 & 64.9 \\
\hline Marjoram & 89.6 & 109.8 & 15.4 & 170.2 \\
\hline peppermint & 57.1 & 33.7 & 8.6 & 50.9 \\
\hline Wild mint & 81.5 & 90.9 & 12.7 & 122.8 \\
\hline Moncut + Oxamyl & 99.0 & 131.9 & 18.9 & 231.6 \\
\hline Control & 42.7 & --- & 5.7 & --- \\
\hline L.S.D. at 0.05 & 4.7 & --- & 2.4 & -- \\
\hline \multicolumn{5}{|c|}{ Season of 2017} \\
\hline Castor bean & 79.4 & 97.0 & 11.6 & 132.0 \\
\hline Damsisa & 56.7 & 40.7 & 8.1 & 62.0 \\
\hline Lantana & 65.9 & 63.5 & 10.0 & 100.0 \\
\hline Marigold & 68.1 & 69.0 & 9.6 & 92.0 \\
\hline Marjoram & 93.8 & 132.8 & 16.1 & 222.0 \\
\hline Peppermint & 58.2 & 44.4 & 8.8 & 76.0 \\
\hline Wild mint & 84.4 & 109.4 & 13.0 & 160.0 \\
\hline Moncut + Oxamyl & 101.5 & 151.9 & 19.2 & 284.0 \\
\hline Control & 40.3 & -- & 5.0 & --- \\
\hline L.S.D. at 0.05 & 4.9 & --- & 2.3 & --- \\
\hline
\end{tabular}

* Increase \% relative to the control. 
The lowest plant height and fruits yield were recorded in plots planted with damsisa plants followed by peppermint treatment without significant differences between them. The corresponding mean values were $25.3 \& 33.7 \%$ and $26.3 \& 50.9 \%$, respectively in the first growing season. Treatment of castor bean-amended soil showed moderate increase in plant height followed by lantana and marigold plots. The same trend was observed in the second growing season (2017).

According to the results obtained from the two growing seasons, it was found that treatments with the two tested biocides (Blight stop and Clean root) either alone or combined with the different plant species in addition to the Moncut + Oxamyl treatment significantly provided protection against Fusarium oxysporum f.sp. lycopersiciMeloidogyne incognita disease complex and affected disease severity at an important level compared to the untreated control (Table, 4). Overall, combined treatments between biocides and each of the tested plant species as intercropping or soil amendments treatments effectively enhanced the level of disease reduction compared to either treatment alone. Blight stop plus any plant species tested were the most effective treatments in decreasing wilt infection than combined treatments with Clean root. The highest efficacy values of the tested plant species and biocides were observed when marjoram as intercropping combined with the biocide Blight stop reduced incidence and severity of Fusarium wilt by 70.0 and $63.6 \%$, respectively during the first growing season, followed by combined treatment between marjoram and the biocide Clean root and wild mint-amended soil combined with Blight stop treatment without significant differences between them. The reduction in wilt incidence and severity due to these treatments, being 66.5, 61.2 and 66.2, 60.7\%, respectively in 2016 growing season and $69.3,67.5$ and $70.2,68.8 \%$ in 2017 growing season, respectively. Combination between wild mint as soil amendment and the biocide Clean root and castor beanamended soil and the biocide Blight stop gave moderate effect in reducing disease severity without significant differences between them followed by plots of castor beanamended soil and the biocide Clean root, peppermint as intercropping + Blight stop which lies in the same statistical group and plots of marigold as intercropping + Blight stop that statistically not differed with peppermint as intercropping + Blight stop treatment. The least effective treatment in minimizing the disease incidence and severity was the biocide Clean root followed by Blight stop followed by combined treatment between damsisa as intercropping + Clean root, lantana as soil amendment + Clean root and damsisa as intercropping + Blight stop without significant differences among them, marigold + Clean root and lantana + Blight stop treatments. The same trend was observed in the second growing season 2017. However, the population of $F$. oxysporum around the rhizosphere of tomato plants was significantly reduced due to the treatments. The high reduction obtained from treatment of tomato-marjoram intercropped combined with the biocide Blight stop was statistically at par after the Moncut + Oxamyl treatment and reduced the population by $82.9 \%$ followed by tomato-marjoram intercropped combined with the biocide Clean root $(81.6 \%)$, treatments of soil 
amended with wild mint combined with each of Blight stop (80.3\%) and Clean root (77.6\%), tomato-peppermint intercropped combined with each of the biocide Blight stop $(76.3 \%)$ and Clean root $(73.7 \%)$. The lowest effect was obtained from application of the biocides individually. The reduction in fungus population due to application of Blight stop was 40.8 and $38.2 \%$ with Clean root treatment. The other treatments showed moderate effect and reduced the population at a promising level.

Table 4: Efficiency of different medicinal and aromatic plants combined with two biocides against wilt of tomato plants and their combined effect on disease severity and population of $F$. oxysporum f.sp. lycopersici $\left(10^{4} \mathrm{spor} / \mathrm{g}\right.$ dry soil) during the two growing seasons.

\begin{tabular}{|c|c|c|c|c|c|c|c|c|c|c|}
\hline \multirow[b]{2}{*}{ Treatments } & \multicolumn{4}{|c|}{ Season of 2016} & \multicolumn{4}{|c|}{ Season of 2017} & \multicolumn{2}{|c|}{$\begin{array}{c}\text { Mean of the } \\
\text { two growing } \\
\text { seasons } \\
\end{array}$} \\
\hline & 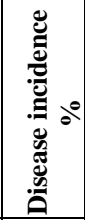 & : & 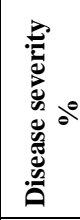 & 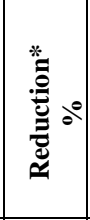 & 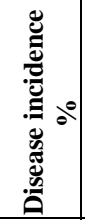 & 昰 & 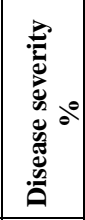 & 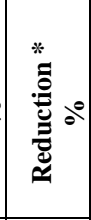 & 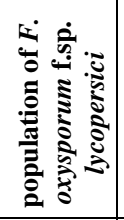 & 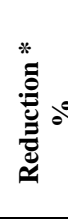 \\
\hline Castor bean + Blight stop & 33.5 & 65.0 & 32.7 & 57.8 & 31.2 & 68.1 & 29.9 & 62.9 & 1.8 & 76.3 \\
\hline Castor bean + Clean root & 35.9 & 62.5 & 34.2 & 55.8 & 34.9 & 64.3 & 31.3 & 61.1 & 2.0 & 73.7 \\
\hline Damsisa + Blight stop & 45.6 & 52.4 & 41.2 & 46.8 & 42.8 & 56.2 & 40.4 & 49.8 & 2.7 & 64.5 \\
\hline Damsisa + Clean root & 48.6 & 49.3 & 44.3 & 42.8 & 48.4 & 50.5 & 43.6 & 45.8 & 2.9 & 61.8 \\
\hline Lantana + Blight stop & 42.4 & 55.7 & 38.5 & 50.3 & 39.2 & 59.9 & 35.7 & 55.7 & 2.5 & 67.1 \\
\hline Lantana + Clean root & 46.0 & 52.0 & 41.7 & 46.1 & 43.6 & 55.4 & 39.9 & 50.4 & 2.7 & 64.5 \\
\hline Marigold + Blight stop & 38.0 & 60.3 & 36.0 & 53.5 & 33.6 & 65.6 & 34.5 & 57.1 & 2.2 & 71.1 \\
\hline Marigold + Clean root & 43.8 & 54.3 & 39.1 & 49.5 & 40.0 & 59.1 & 38.4 & 52.3 & 2.4 & 68.4 \\
\hline Marjoram + Blight stop & 28.7 & 70.0 & 28.2 & 63.6 & 24.6 & 74.8 & 23.5 & 70.8 & 1.3 & 82.9 \\
\hline Marjoram + Clean root & 32.1 & 66.5 & 30.0 & 61.2 & 30.0 & 69.3 & 26.2 & 67.5 & 1.4 & 81.6 \\
\hline Peppermint+ Blight stop & 36.2 & 62.2 & 34.8 & 55.0 & 34.6 & 64.6 & 31.6 & 60.7 & 1.8 & 76.3 \\
\hline Peppermint + Clean root & 38.5 & 59.8 & 36.7 & 52.6 & 38.8 & 60.3 & 34.5 & 57.1 & 2.0 & 73.7 \\
\hline Wild mint + Blight stop & 32.4 & 66.2 & 30.4 & 60.7 & 29.1 & 70.2 & 25.1 & 68.8 & 1.5 & 80.3 \\
\hline Wild mint + Clean root & 33.6 & 64.9 & 32.6 & 57.9 & 30.6 & 68.7 & 29.2 & 63.7 & 1.7 & 77.6 \\
\hline Blight stop & 47.4 & 50.5 & 45.2 & 41.6 & 43.2 & 55.8 & 44.6 & 44.6 & 4.5 & 40.8 \\
\hline Clean root & 53.4 & 44.3 & 49.4 & 36.2 & 52.5 & 46.3 & 48.7 & 39.5 & 4.7 & 38.2 \\
\hline Moncut + Oxamyl & 33.7 & 64.8 & 25.3 & 67.3 & 32.0 & 67.2 & 22.2 & 72.4 & 1.1 & 85.5 \\
\hline Control & 95.8 & 0.0 & 77.4 & --- & 97.7 & 0.0 & 80.5 & $\begin{array}{ll}-- \\
\end{array}$ & 7.6 & --- \\
\hline L.S.D. at 0.05 & 1.1 & 2.0 & 1.5 & --- & 1.7 & 3.3 & 2.2 & --- & 0.1 & --- \\
\hline
\end{tabular}

* Reduction \% relative to the control. 
The two biocides (Blight stop and Clean root) used alone or combined with different plant species tested significantly reduced gall formation, no. of egg masses and no. of developmental stages in tomato root system as well as population of M. incognita in soil, final population and its reproduction factor compared to the untreated control (Tables, 5 and 6). Generally, combined use of each biocide and any of the plant species tested was more effective than their individual use in this respect. However, effects varied among the treatments, the lowest number of root galling (7), egg mass (5) and developmental stage (9) in root system occurred in plots treated with the Moncut + Oxamyl, followed by combined treatment between marjoram as intercropping and Blight stop which statistically lies in the same group with the Moncut + Oxamyl treatment. The corresponding mean values of nematode parameters obtained from this treatment were 9,8 and 17 , respectively followed by combined use of marjoram + Clean root treatment without significant differences between them followed by plots received wild mint as soil amendment + Blight stop and castor bean as soil amendment + Blight stop which reduced no. of root galling to $14,17 \& 18$, egg mass to $12,12 \& 19$ and developmental stage to $18,19 \& 24$, respectively without significant differences among them except in parameter of developmental stage number during 2016 growing season. The same trend was obtained in the second growing season 2017. It is worthy to note that the biocide Blight stop was more effective than Clean root in reducing infection of root knot nematode.

The final M. incognita population in the soil at the end of the experiments and its reproduction factor were severely affected by the tested treatments in the two growing seasons. In this respect, intercropping marjoram with tomato plants combined with Blight stop or Clean root and wild mint as soil amendment combined with Blight stop showed the highest efficiency compared to the other treatments without significant differences among them except in parameter of reproduction factor with combined use of marjoram and Blight stop treatment which showed significant differences with the other treatments. The corresponding mean values of final nematode population, being $84,101 \& 111$ and $0.04,0.05 \& 0.05$ in reproduction rate, respectively in the first growing season 2016. Castor bean-amended soil + Blight stop and wild mint-amended soil + Clean root treatments came next in their efficiencies with no significant differences except in reproduction rate which show moderately effect in reducing final nematode population in soil $(125 \& 144)$ and reproduction rate $(0.06 \& 0.07)$, respectively. The lowest effect was obtained due to using the biocide Clean root. The same trend was observed in the second growing season (2017). 
Table 5: Combined effect of different medicinal and aromatic plants and two biocides on nematode parameters during the growing season 2016 under field conditions.

\begin{tabular}{|c|c|c|c|c|c|c|}
\hline Treatments & 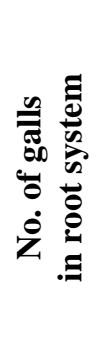 & 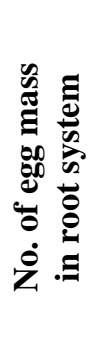 & 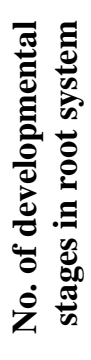 & 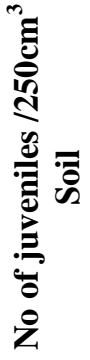 & 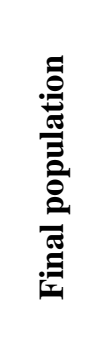 & 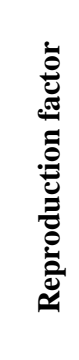 \\
\hline Castor bean + Blight stop & 18 & 19 & 24 & 82 & 125 & 0.06 \\
\hline Castor bean + Clean root & 28 & 23 & 47 & 107 & 177 & 0.09 \\
\hline Damsisa + Blight stop & 61 & 42 & 124 & 203 & 369 & 0.18 \\
\hline Damsisa + Clean root & 67 & 51 & 127 & 300 & 478 & 0.24 \\
\hline Lantana + Blight stop & 47 & 31 & 71 & 191 & 293 & 0.15 \\
\hline Lantana + Clean root & 52 & 34 & 118 & 200 & 352 & 0.18 \\
\hline Marigold + Blight stop & 36 & 31 & 63 & 132 & 226 & 0.11 \\
\hline Marigold + Clean root & 42 & 32 & 67 & 138 & 237 & 0.12 \\
\hline Marjoram + Blight stop & 9 & 8 & 17 & 59 & 84 & 0.04 \\
\hline Marjoram + Clean root & 14 & 12 & 18 & 71 & 101 & 0.05 \\
\hline Peppermint + Blight stop & 32 & 22 & 24 & 124 & 170 & 0.09 \\
\hline Peppermint + Clean root & 37 & 25 & 57 & 131 & 213 & 0.11 \\
\hline Wild mint + Blight stop & 17 & 12 & 19 & 80 & 111 & 0.05 \\
\hline Wild mint + Clean root & 27 & 22 & 24 & 98 & 144 & $\mathbf{0 . 0 7}$ \\
\hline Blight stop & 81 & 64 & 134 & 309 & 507 & 0.25 \\
\hline Clean root & 87 & 98 & 140 & 660 & 898 & 0.45 \\
\hline Moncut + Oxamyl & 7 & 5 & 9 & 50 & 64 & $\mathbf{0 . 0 3}$ \\
\hline Control & 971 & 840 & 510 & 2020 & 3370 & 1.69 \\
\hline L.S.D. at 0.05 & 5.3 & 4.7 & 8.4 & 21.3 & 53.6 & 0.01 \\
\hline
\end{tabular}

Egypt. J. Phytopathol., Vol. 46, No. 2 (2018) 
Table 6: Combined effect of different medicinal and aromatic plants and two biocides on nematode parameters during the growing season 2017 under field conditions.

\begin{tabular}{|c|c|c|c|c|c|c|}
\hline Treatments & 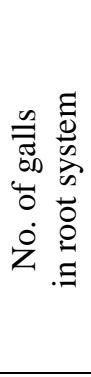 & 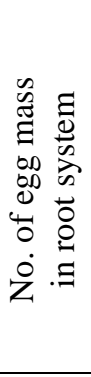 & 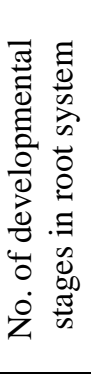 & 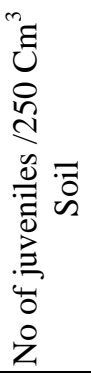 & 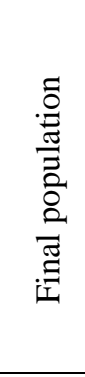 & 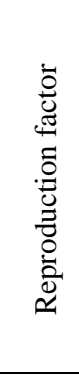 \\
\hline Castor bean + Blight stop & 17 & 11 & 17 & 70 & 98 & 0.07 \\
\hline Castor bean + Clean root & 29 & 17 & 30 & 86 & 133 & 0.09 \\
\hline Damsisa + Blight stop & 62 & 35 & 101 & 160 & 296 & 0.20 \\
\hline Damsisa + Clean root & 63 & 47 & 120 & 255 & 422 & 0.28 \\
\hline Lantana + Blight stop & 45 & 29 & 65 & 130 & 224 & 0.15 \\
\hline Lantana + Clean root & 51 & 25 & 91 & 140 & 256 & 0.17 \\
\hline Marigold + Blight stop & 33 & 21 & 51 & 93 & 165 & 0.11 \\
\hline Marigold + Clean root & 43 & 25 & 60 & 116 & 201 & 0.13 \\
\hline Marjoram + Blight stop & 6 & 4 & 10 & 30 & 44 & 0.03 \\
\hline Marjoram + Clean root & 11 & 9 & 15 & 51 & 75 & 0.05 \\
\hline Peppermint + Blight stop & 30 & 19 & 20 & 89 & 128 & 0.09 \\
\hline Peppermint + Clean root & 34 & 21 & 45 & 99 & 165 & 0.11 \\
\hline Wild mint + Blight stop & 14 & 7 & 16 & 55 & 78 & 0.05 \\
\hline Wild mint + Clean root & 19 & 13 & 20 & 63 & 96 & 0.06 \\
\hline Blight stop & 75 & 64 & 125 & 200 & 389 & 0.26 \\
\hline Clean root & 80 & 90 & 141 & 506 & 737 & 0.49 \\
\hline Moncut + Oxamyl & 8 & 4 & 9 & 20 & 33 & 0.02 \\
\hline Control & 995 & 890 & 611 & 4600 & 6101 & 4.07 \\
\hline L.S.D. at 0.05 & 4.0 & 5.6 & 6.0 & 17.8 & 71.0 & 0.02 \\
\hline
\end{tabular}

Results presented in Table, 7 indicate that all of the tested biocides either alone or combined with plant species were significantly effective in exhibiting the highest plants and the best tomato fruits yield with regard to untreated control. The highest plant height and fruits yield were observed in plots treated with combination of marjoram as intercropping and the biocide Blight stop which was statistically at par with the Moncut 
+ Oxamyl treatment followed by plots treated with marjoram + Clean root and wild mint-amended soil + Blight stop without significant differences between them . The percentages of increase in the tomato plant height and fruits yield as a result of these treatments were $129.3,120.4 \& 118.7 \%$ and $226.3,205.3 \& 203.5 \%$ in the first growing season, respectively and being $145.7,138.7 \& 138.0 \%$ and $276.0,258.0 \&$ $254.0 \%$ in the second growing season, respectively. The lowest plant height and fruits yield were recorded in plots treated with the biocide Clean root followed by Blight stop treatment. The corresponding increase in plant height was $33.3 \& 46.4 \%$, respectively and being $57.9 \& 89.5 \%$ in fruits yield, respectively during 2016 growing season. The same trend was observed in the second season 2017. In general, Plots treated with combination of plant species and biocides showed more increase in plant height and fruits yield than when each treatment was applied alone. However, plots treated with combination of plant species and the biocide Blight stop were more higher and produced more fruit yield than plots treated with combination of plant species and the biocide Clean root.

Table 7: Combined effect of different medicinal and aromatic plants and two biocides on tomato plant height $(\mathrm{cm})$ and fruits yield (ton/fed.) during the two growing seasons 2016 and 2017 under field conditions.

\begin{tabular}{|c|c|c|c|c|c|c|c|c|}
\hline \multirow[b]{2}{*}{ Treatments } & \multicolumn{4}{|c|}{ Season of 2016} & \multicolumn{4}{|c|}{ Season of 2017} \\
\hline & 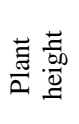 & 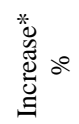 & 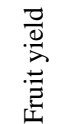 & 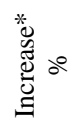 & 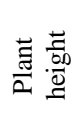 & 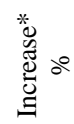 & 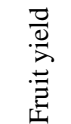 & 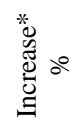 \\
\hline Castor bean + Blight stop & 90.7 & 112.4 & 17.2 & 201.8 & 94.0 & 133.3 & 17.5 & 250.0 \\
\hline Castor bean + Clean root & 88.5 & 107.3 & 16.2 & 184.2 & 91.5 & 127.0 & 16.6 & 232.0 \\
\hline Damsisa + Blight stop & 75.6 & 77.0 & 12.0 & 110.5 & 77.3 & 91.8 & 12.3 & 146.0 \\
\hline Damsisa + Clean root & 70.6 & 65.3 & 11.9 & 108.8 & 71.5 & 77.4 & 11.8 & 136.0 \\
\hline Lantana + Blight stop & 83.1 & 94.6 & 14.4 & 152.6 & 86.6 & 114.9 & 14.9 & 198.0 \\
\hline Lantana + Clean root & 81.5 & 90.9 & 14.3 & 150.9 & 84.8 & 110.4 & 14.6 & 192.0 \\
\hline Marigold + Blight stop & 86.0 & 101.4 & 15.7 & 175.4 & 87.8 & 117.9 & 15.8 & 216.0 \\
\hline Marigold + Clean root & 85.7 & 100.7 & 15.0 & 163.2 & 87.4 & 116.9 & 15.2 & 204.0 \\
\hline Marjoram + Blight stop & 97.9 & 129.3 & 18.6 & 226.3 & 99.0 & 145.7 & 18.8 & 276.0 \\
\hline Marjoram + Clean root & 94.1 & 120.4 & 17.4 & 205.3 & 96.2 & 138.7 & 17.9 & 258.0 \\
\hline Peppermint + Blight stop & 79.5 & 86.2 & 13.5 & 136.8 & 82.8 & 105.5 & 13.7 & 174.0 \\
\hline Peppermint + Clean root & 79.3 & 85.7 & 12.1 & 112.3 & 80.6 & 100.0 & 12.4 & 148.0 \\
\hline Wild mint + Blight stop & 93.4 & 118.7 & 17.3 & 203.5 & 95.9 & 138.0 & 17.7 & 254.0 \\
\hline Wild mint + Clean root & 90.6 & 112.2 & 16.7 & 193.0 & 93.7 & 132.5 & 16.9 & 238.0 \\
\hline Blight stop & 62.5 & 46.4 & 10.8 & 89.5 & 64.6 & 60.3 & 10.5 & 110.0 \\
\hline Clean root & 56.9 & 33.3 & 9.0 & 57.9 & 60.4 & 49.9 & 9.2 & 84.0 \\
\hline Moncut + Oxamyl & 99.0 & 131.9 & 18.9 & 231.6 & 101.5 & 151.9 & 19.2 & 284.0 \\
\hline Control & 42.7 & --- & 5.7 & --- & 40.3 & --- & 5.0 & --- \\
\hline L.S.D. at 0.05 & 3.2 & --- & 0.4 & --- & 3.1 & --- & 0.2 & $\begin{array}{c}--- \\
-1\end{array}$ \\
\hline
\end{tabular}

$*$ increase $\%$ relative to the control.

Egypt. J. Phytopathol., Vol. 46, No. 2 (2018) 
The population density of Bacillus sp. and Trichoderma sp. were significantly increased in plots intercropped with plant species or amended with plant residues than plots treated with the biocides only (Table, 8). Microbial populations varied with date of sampling and treatments. Tomato-marjoram intercropped plots showed the maximum population density of Bacillus sp. and Trichoderma sp. which recorded 137.2 and 165.5 $\%$, respectively followed by wild mint-amended soil and castor bean-amended soil plots. Plots of tomato-damsisa intercrop showed the lowest density of microbial population. The populations of Bacillus sp. and Trichoderma sp. showed a dramatic increase at three intervals which reached the maximum values at 120 day after transplanting.

Table 8: Effect of different medicinal and aromatic plants on total numbers of Trichoderma sp. $\left(10^{4}\right.$ spore/g dry soil $)$ and Bacillus $\mathrm{sp} .\left(10^{6} \mathrm{cfu} / \mathrm{g}\right.$ dry soil $)$ during the two growing seasons 2016 and 2017 under field conditions.

\begin{tabular}{|c|c|c|c|c|c|c|c|c|c|c|}
\hline \multirow{3}{*}{ Treatments } & \multicolumn{10}{|c|}{ Mean of the two growing seasons } \\
\hline & \multicolumn{5}{|c|}{ Bacillus sp. } & \multicolumn{5}{|c|}{ Trichoderma sp. } \\
\hline & $\underset{r}{\stackrel{5}{a}}$ & $\begin{array}{l}5 \\
8 \\
8\end{array}$ & $\begin{array}{l}\text { S. } \\
\text { ปิ }\end{array}$ & $\sum_{\Sigma}^{\bar{E}}$ & 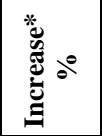 & 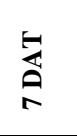 & $\begin{array}{l}5 \\
8 \\
8\end{array}$ & $\begin{array}{l}\text { 帘 } \\
\text { ฮิ }\end{array}$ & $\stackrel{\Xi}{\Sigma}$ & 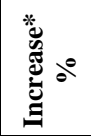 \\
\hline Castor bean & 39.4 & 63.7 & 80.1 & 61.5 & 113.5 & 4.9 & 6.4 & 8.1 & 6.5 & 124.1 \\
\hline Damsisa & 28.9 & 43.1 & 67.7 & 46.3 & 60.8 & 3.0 & 3.6 & 5.1 & 3.9 & 34.5 \\
\hline Lantana & 30.6 & 51.0 & 69.1 & 50.2 & 74.3 & 3.2 & 4.1 & 5.5 & 4.3 & 48.3 \\
\hline Marigold & 31.6 & 53.3 & 73.0 & 52.6 & 82.6 & 3.7 & 5.6 & 6.3 & 5.2 & 79.3 \\
\hline Marjoram & 45.0 & 70.0 & 91.0 & 68.3 & 137.2 & 6.2 & 7.2 & 9.6 & 7.7 & 165.5 \\
\hline peppermint & 33.2 & 56.6 & 77.0 & 55.7 & 93.4 & 4.4 & 6.0 & 7.1 & 5.8 & 100.0 \\
\hline Wild mint & 42.0 & 67.2 & 86.1 & 65.1 & 126.0 & 5.7 & 6.7 & 8.7 & 7.0 & 141.4 \\
\hline Biocides & 17.9 & 27.9 & 40.5 & 28.8 & --- & 2.3 & 2.8 & 3.7 & 2.9 & --- \\
\hline L.S.D. at 0.05 & 2.6 & 3.8 & 5.7 & --- & --- & 0.4 & 0.2 & 0.3 & --- & --- \\
\hline
\end{tabular}

DAT $=$ Day after transplanting.

* Increase \% relative to the biocides tested. 


\section{Discussion}

Within the bank of natural fungicides and nematicides that present in plant species that would serve as safe and effective alternatives to synthetic fungicides and nematicides. These compounds (volatile components, essential oils), if formulated, could be used directly and serve as alternative for synthetic analogs. The nematicidal activity of the components of essential oils from different plants may be due to the fact that the lipophilic molecules of essential oils pass freely through the cell wall and cytoplasmic membrane. They disrupt the lipopolysaccharide layers, phospholipid, and fatty acids, making them permeable (Nazzaro et al., 2013). In the present study it was observed that the tested medicinal and aromatic plants used as intercropping or soil amendments either alone or in combination with the biocides have the capability to reduce damage occurred by Fusarium wilt-root knot disease complex on tomato plant at an satisfactory level. These treatments significantly reduced no. of galls formed, egg hatching, numbers of $\mathrm{J}_{2}$ of $M$. incognita and its reproduction rate as well as decreased severity of $F$. oxysporum f.sp. lycopersici. A combined use of each biocide and any of the plant species tested was more effective than their individual use in this respect. Combined treatment between marjoram as intercropping and the biocide Blight stop had a superior effect in controlling the complex disease out of all treatments followed by combined treatment between marjoram as intercropping and the biocide Clean root and combination between wild mint as soil amendment and Blight stop. The major components carvacrol and thymol in marjoram and isopelugone in wild mint were very effective in $J_{2}$ immobilization and hatching inhibition (Soler-Serratosa et al., 1996 and Yuji Oka et al. 2000). Preplant treatments of phytoparasitic nematodes lead to sharp reduction in disease incidence; three possible explanations may be postulated: (i) stimulation of a beneficial microflora by the compounds or the products of their degradation; (ii) altered host response; (iii) establishment of a physico-chemical environment deleterious to phytonematodes (Soler-Serratosa et al. 1996). Kloepper et al. (1992) demonstrated that thymol stimulated a particular microflora capable of inducing host resistance or promoting nematode antagonism. The allelopathic effect of marigold that is responsible for suppression of nematode and other plant pathogens is mainly attributed to $\alpha$-terthienyl (Stirling et al., 1992). Marigold kills plant-parasitic nematodes as a standing cover crop and is ineffective after soil incorporation. It is found that the nematicidal activity of marigold was only detected in the root exudates but not in the homogenized extracts of roots and leaves (Tsay et al., 2004). Planting of marigolds for 65 to 105 days in field highly infested with root-knot nematodes resulted in significant decrease of nematode populations and increase in yields of subsequent crop up to $98 \%$ (Ploeg, 1999). In this study, the cultivation of marigold consistently resulted in a yield increase of 64.9-92.0 \% and decreased root-galling of subsequently grown tomato. The results were in agreement with Olabiyi (2008). Adomako \& Kwoseh (2013) showed that inhibition of egg hatch and the number of dead root-knot juveniles was increased with increasing concentration of the castor bean aqueous extract. The 
highest egg inhibition was recorded in the crude extract. Egg hatch inhibition and juvenile mortality also were increased with increase in exposure time. Ricin, the principal toxin in castor seed is described as a toxalbumin and this is a protein phytotoxin that is capable of inhibiting protein synthesis. El-Mougy et al., (2007) observed that mint essential oils mainly menthol were able to prevent the growth of $F$. oxysporum f.sp. phaseoli under in vitro conditions. It seems that the antifungal effects are the result of compounds present in the essential oils acting synergistically. This means that the individual components by themselves are not sufficiently effective. The mode of action by which microorganisms are inhibited by essential oils and their chemical compounds, seem to involve different mechanisms. It has been hypothesized that the inhibition involves phenolic compounds, because these compounds sensitize the phospholipid bilayer of the microbial cytoplasmic membrane causing increased permeability and unavailability of vital intracellular constituents (Juven, 1994). Effect of specific ions due to their addition in/on plasmatic membrane had great an effect on the protons motive force, intracellular ATP content and overall activity of microbial cells, including turgor pressure control, solutes transport and metabolism regulation (Lanciotti, 2004). A nematicidal compound enepentyne from Ambrosia artemisifolia when applied in soil significantly reduced egg masses and root galls in tomatoes and increase shoot to fresh and dry weight (Stirling et al., 1992). Qamar et al. (2005) found that lantanilic acid, camaric acid and oleanolic acid isolated from the methanolic extract of the aerial parts of Lantana camara through exhibited significant mortality against root-knot nematode Meloidogyne incognita at $0.5 \%$ concentration. However, Feyisa et al., (2015) found that L. camara act as substrate for the growth and multiplication of $T$. harzianum. Decomposed leaves have been found to support greater sporulation and multiplication of $T$. harzianum.

The present study showed that the biocide Blight stop (Trichoderma sp.) revealed significant biocontrol activity against Fusarium wilt-root knot nematode disease complex than the biocide Clean root (Bacillus sp.) under field conditions. Trichoderma species show strong antagonistic activity against many soilborne fungi including Fusarium sp. (Ayed et al., 2006) and root knot nematode. The success of Trichoderma as a biocontrol agent is believed to involve various modes of action, including antibiotic production, secretion of lytic enzymes and direct penetration of the host hyphae. Also, Trichoderma spp., caused colonization of lateral roots which may acts as a barrier for the invation and colonization by the fungus. The hydrolytic enzymes, such as chitinase, glucanase and protease, produced by Trichoderma may play a key role in its ability to penetrate and kill a host fungus, digest the cuticle of $M$. incognita $\mathrm{J}_{2}$ because the $\mathrm{J}_{2}$ cuticle is composed mainly of proteins and destroy cell wall integrity, resulting in $\mathbf{J}_{2}$ death (Sharon et al., 2001). Dos Santos et al. (1992) reported T. harzianum as an effective egg parasite of $M$. incognita which was able to grow on the egg surface and penetrated the egg shell. The biocide Clean root (Bacillus sp.) was able to significantly reduce severity of Fusarium wilt as well as galls, egg masses, developmental stage on 
tomato root system and final population of nematode in soil and its reproduction rate compared with the untreated control. The results are in accordance with previous work (Roy et al., 2015). Bacteria show antagonistic activity against the soilborne fungi and root-knot nematode $M$. incognita through nematicidal, nematostatic or repellant bacterial compounds or parasitism on juveniles or eggs which causes lysis of nematode eggs and affects vitality of $J_{2}$ of root-knot nematodes and induction of systemic resistance. Bacillus subtilis has the capacity to colonize plant roots and does not leave enough roots for the invasion by pathogenic hyphae (Shahid and Khan, 2016).

On the other hand, all plant species tested did not show any negative effects on plant growth except with tomato-peppermint and tomato-damsisa intercrop treatments. This may be that damsisa and peppermint plants occupied more space on the plots than other plant species by covering the soil with network of runners (in case of peppermint) or shadowing soil and tomato plants with its leaves (in the case of damsisa). Thus, it is suggested that damsisa and peppermint competed with tomato plants for abiotic resources (i.e., space, nutrients, water), more than the other studies plant species. It is suggested that tomato plants responded to intense biotic interaction with peppermint and damsisa by producing fruits factor (de Carvalho et al., 2012). Plots treated with combination of plant species and biocides showed more plant height and fruits yield than each treatment applied alone. The addition of botanicals to soil leads to a better environment for the growth of the roots. This enhances the utilization of soil nutrients, as a consequence of which the nematode damage might have been markedly reduced (Adomako \& Kwoseh, 2013). These botanicals may be act as substrate for the growth and multiplication of beneficial microorganisms which have synergistic effect. Bacillus and Trichoderma are better known as plant growth promoters which enhanced plant growth and reduced root-knot nematode damage (Minaxi et al., 2012). Trichoderma spp. produces plant growth promoting factors and secondary metabolites which may act as auxin like compound, increased nutrient availability that leads to enhancement of plant growth and consequently, increase crop yield. Also help in tolerance to stress condition by enhanced root development. It participates in solubilization of inorganic nutrients (Sharma and Pandey, 2009). Bacillus subtilis strains were able to promote root elongation in seedlings and improved the growth characteristics (length and weight of shoot and root) of tomato plants leading to simultaneous increase of fruit yield (Roy et al., 2015).

\section{Conclusions}

The biocides and plant species used have potential in crop management and can be used to reduce the deleterious impact of Fusarium wilt-root knot disease complex in tomato plants under field conditions.

\section{References}

Abd-El-Khair, H.; Wafaa M.A. El-Nagdi and Hammam, M.M.A. 2018. Effect of olive and castor bean oil cakes singly or combined with Trichoderma spp. on Fusarium

Egypt. J. Phytopathol., Vol. 46, No. 2 (2018) 
solani and Meloidogyne incognita infecting eggplant. Middle East J. Appl. Sci., 8(2): 465-473.

Abo-Elyousr, K.A. and Mohamed, H.M. 2009. Biological control of Fusarium wilt in tomato by plant growth-promoting yeasts and rhizobacteria. Plant Pathol. J., 25(2): 199-204.

Adomako, J. and Kwoseh, C.K. 2013. Effect of castor bean (Ricinus communis L.) aqueous extracts on the performance of root-knot nematodes (Meloidogyne spp.) on tomato (Solanum lycopersicum L.). J. Sci. Technol., 33(1): 1-11.

Ayed, F.; Daami-Remadi, M.; Jabnoun-Khiareddine, H. and El Mahjoub, M. 2006. Potato vascular Fusarium wilt in Tunisia: Incidence and biocontrol by Trichoderma spp. Plant Pathol. J., 5(1): 92-98.

de Carvalho, L.M.; de Oliveira, I.R.; Almeida, N.A. and Andrade, K.R. 2012. The effects of biotic interaction between tomato and companion plants on yield, Acta Horticulturae, 933: 347-354.

Dos Santos, M.A.; Ferraz, S. and Muchovez, J.J. 1992. Evaluation of 20 species of fungi from Brazil for biocontrol of Meloidogyne incognita race-3. Nematropica, 22: 183-192.

Elad Y.; Chet, I. and Henis, Y. 1981. A selective medium for improving quantitative isolation of Trichoderma spp. from soil. Phytoparasitica, 9: 59-67.

El-Mougy, N.S.; El-Gamal, N.G.; Mokhtar M. and Abdel-Kader, M.M. 2007. Control of wilt and root rot incidence in Phaseolus vulgaris L. by some plant volatile compounds. Journal of Plant Protection Research, 47(3): 255-265.

Feyisa, B.; Lencho, A.; Selvaraj, T. and Getaneh, G. 2015. Evaluation of some botanicals and Trichoderma harzianum for the management of tomato root-knot nematode (Meloidogyne incognita (Kofoid and White) Chit Wood). Adv. Crop Sci. Tech., 4(1): 1-10.

Hussain, M.A.; Mukhtar, T. and Kayani, M.Z. 2011. Efficacy evaluation of Azadirachta indica, Calotropis procera, Datura stramonium and Tagetes erecta against root-knot nematodes Meloidogyne incognita. Pak. J. Bot., 43: 197-204.

Juven, B.J.; Kanner, J.; Sched, F. and Weisslowicz, H. 1994. Factors that interact with the antibacterial of thyme essential oil and its active constituents. J. Appl. Microbiol., 76: 626-631.

Kloepper, J.W.; Rodriguez-Kábana, R.; McInroy, J.A. and Young, R.W. 1992. Rhizosphere bacteria antagonistic to soybean cyst (Heterodera glycines) and rootknot (Meloidogyne incognita) nematodes: identification by fatty acid analysis and frequency of biocontrol activity. Plant Soil, 139: 75-84.

Egypt. J. Phytopathol., Vol. 46, No. 2 (2018) 
Kumar, N.; Bhatt, J. and Sharma, R.L. 2017. Interaction between Meloidogyne incognita with Fusarium oxysporum f.sp. lycpersici on tomato. Int. J. Curr. Microbiol. App. Sci., 6(8): 1770-1776.

Lanciotti, R.; Gianotti, A.; Patrignani, N.; Belleti, N.; Guerzoni, M.E. and Gardini, F. 2004. Use of natural aroma compounds to improve shelf-life of minimally processed fruits. Trends. Food Sci. Technol., 15: 201-208.

Mafeo, T.P. and Mashela, P.W. 2010. Allelopathic inhibition of seedling emergence in dicotyledonous crops by Cucumis bio-nematicide. African J. Biotech., 9(49): 83498354.

Minaxi, L.N.; Yadav, R.C. and Saxena, J. 2012. Characterisation of multifaceted Bacillus sp. RM-2 for its use as plant growth promoting bio-inoculant for crops grown in semi arid deserts. Appl. Soil Ecol., 59:124-135.

Munawar, M.; Khan, S.A.; Javed, N.; Haq, I.U. and Gondal, A.S. 2015. Biomanagement of tomato wilt complex caused by Meloidogyne incognita and Fusarium oxysporum f.sp. lycopersici. Nematology, 17: 479-485.

Nahak, G. and Sahu, R.K. 2017. Bio-controlling effect of leaf extract of Tagetes patula L. (marigold) on growth parameters and diseases of tomato. Pakistan J. Biol. Sci., 20(1): 12-19.

Nazzaro, F.; Fratianni, F.; De Martino, L.; Coppola, R. and De Feo, V. 2013. Effect of essential oils on pathogenic bacteria. Pharmaceuticals, 6(12): 1451-1474.

Norton, D.C. 1978. Ecology of Plant Parasitic Nematode. John Willey and Sons, New York, USA. 238 pp.

Olabiyi, T.I. 2008. Pathogenicity study and nematoxic properties of some plant extracts on the root-knot nematode pest of tomato, Lycopersicon esculentum. Plant Pathol. J., 7(1): 45-49.

Ploeg, A.T. 1999. Greenhouse studies on the effect of marigolds (Tagetes sp.) on four Meloidogyne species. J. nematol., 11: 369-370.

Qamar, F.; Begum, S.; Raza, S.M.; Wahab, A. and Siddiqui, B.S. 2005. Nematicidal natural products from the aerial parts of Lantana camara Linn. Natural Product Research, 19(6): 609-613.

Roy, S.; Rathod, A. and Aniruddha Pramanik, A. 2015. Bioefficacy of Bacillus subtilis against root knot nematode Meloidogyne incognita (Kofoid and White) Chitwood in tomato. J. Appl. \& Nat. Sci., 7(2): 1012-1015.

Schneider, S. and Ullrich, W.R. 1994. Differential induction of resistance and enhanced enzyme activities in cucumber and tobacco caused by treatment with various abiotic and biotic inducers. Physiol. Mol. Plant Pathol., 45: 291-304.

Egypt. J. Phytopathol., Vol. 46, No. 2 (2018) 
Shahid, S. and Khan, M.R. 2016. Biological control of root-rot on mungbean plants incited by Macrophomina phaseolina through microbial antagonists. Plant Pathol. J., 15(2): 27-39.

Sharma, P. and Pandey, R. 2009. Biological control of root-knot nematode, Meloidogyne incognita in the medicinal plant, Withania somnifera and the effect of bio-control agents on plant growth. African J. Agric. Res., 4: 564-567.

Sharon, E.; Bar-Eyal, M.; Chet, I.; Herrera-Estrella, A.; Kleifeld, O. and Spiegel, Y. 2001. Biological control of the root-knot nematode Meloidogyne javanica by Trichoderma harzianum. Phytopathology, 91(7): 687-693.

Snedecor, G.W. and Cochran, W.G. 1989. "Statistical Methods". 8th. ed. Iowa State Univ. Press, Ames, Iowa, USA, 251 pp.

Snyder, W.C. and Hans, H.N. 2003. Fusarium oxysporum f.sp. lycopersici (Sacc.) and Prepared by Mui-Yun Wong Soil borne Plant Pathogen Class Project, Spring, PP. 728.

Soler-Serratosa, A.; Kokalis-Burelle, N.; Rodríguez-Kábana, R.; Weaver, C.F. and King, P.S. 1996. Allalochemicals for control of plant-parasitic nematodes. 1. In vivo nematicidal efficacy of thymol and thymol/benzaldehyde combinations. Nematropica, 26: 57-71.

Stirling, G.R.; Stanton, J.M. and Marshalls, J.W. 1992. The importance of plant parasitic nematodes to tropical agriculture. Aust. Plant Pathol. J., 21: 104-106.

Sukul, N.C. 1992 Plant antagonistic to plant parasitic nematode. Indian Rev. Life Sci., 12: $23-52$.

Tsay, T.T.; Wu, S.T. and Lin, Y.Y. 2004. Evaluation of Asteraceae plants for control of Meloidogyne incognita. J. nematol., 36(1): 36-41.

Uma Maheshwari, T.; Sharma, S.B.; Reddy, D.D.R. and Haware, M.P. 1997. Interaction of Fusarium oxysporum f.sp. ciceri and Meloidogyne javanica on Cicer arietinum. J. Nematol., 29:117-126.

Yuji Oka; Nacar, S.; Putievsky, E.; Ravid, U.; Yaniv, Z. and Spiegel, Y. 2000. Nematicidal activity of essential oils and their components against the root-knot nematode. Phytopathology., 90(7): 710-715.

Zaker, M. 2014. Antifungal evaluation of some plant extracts in controlling Fusarium solani, the causal agent of potato dry rot in vitro and in vivo. Inter. J. Agri. Biosci., 3(4): 190-195.

(Received 05/08/2018;

in revised form 23/09/2018) 


\section{كفاءة بعض النباتات الطبية والعطرية اضافة الى المبيدات

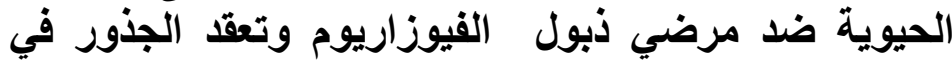 الطماطم \\ فرج محم فرجم ـ ايمان وجيه راغب غبريال2 ـ هناء سيدهم زوام3 \\ 1- قسم بحوث أمراض الخضر ، معهُ بحوث أمراض النباتات ، مركز البحوث

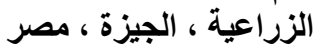

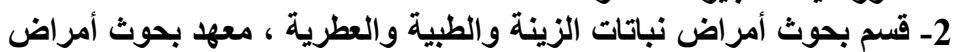

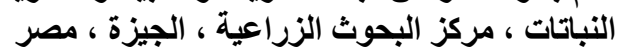

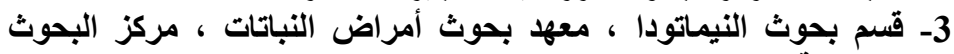

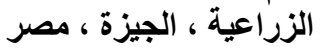

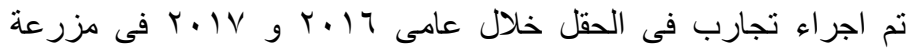

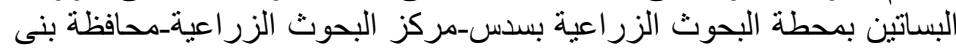

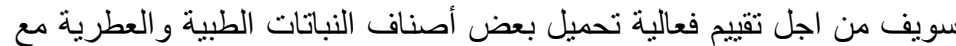

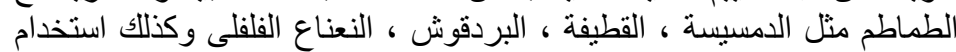

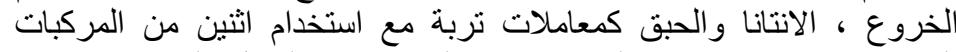

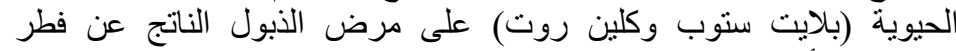

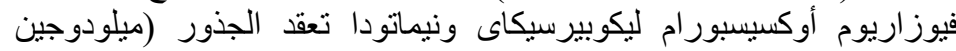

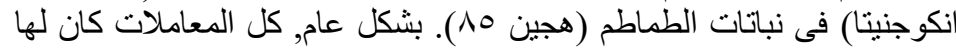

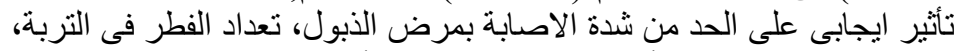

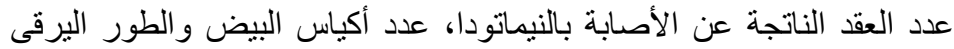

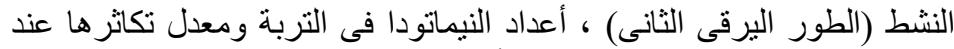

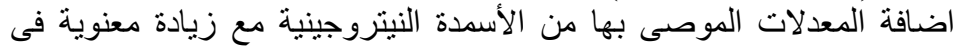

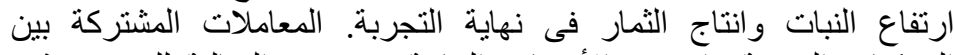

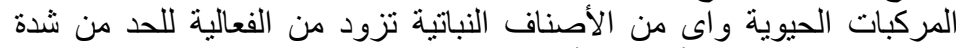

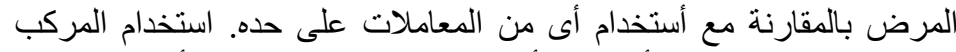

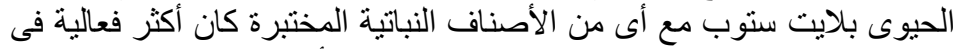

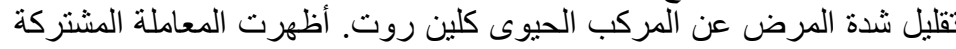

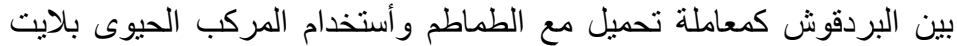

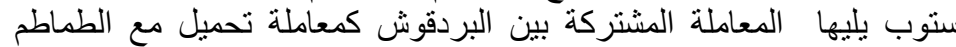

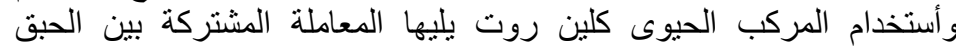

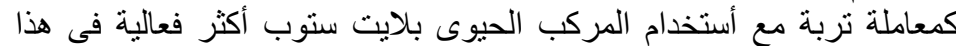

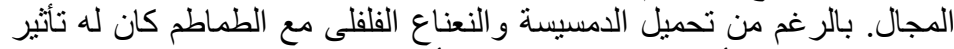

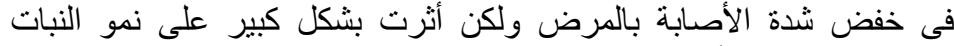
و انتاجية الثمار الى أدنى قيمة. 